\title{
Meta-Analyses of Intracerebral Hematoma Treatment
}

\section{Intraserebral Hematom Tedavisi Metaanalizi}

\author{
Ihsan ANIK ${ }^{1}$, Halil Ibrahim SECER ${ }^{2}$, Yonca ANIK ${ }^{3}$, Bulent DUZ², Engin GONUL ${ }^{2}$ \\ ${ }^{1}$ Kocaeli University, Faculty of Medicine, Department of Neurosurgery, Kocaeli, Turkey \\ ${ }^{2}$ Gulhane Military Medical Academy, Department of Neurosurgery, Ankara, Turkey \\ ${ }^{3}$ Kocaeli University, Faculty of Medicine, Department of Radiology, Kocaeli, Turkey
}

Correspondence address: Ihsan ANIK / E-mail: drianik@gmail.com

\begin{abstract}
AIM: The aim of this study is to define the position of surgery preference in the treatment choice for spontaneous intracerebral hematoma $(\mathrm{ICH})$ and to compare the efficacy of surgery with the medical treatment based on data from 18 previously reported randomized prospective studies on this topic.

MATERIAL and METHODS: Literature databases and articles were searched from 1960 to 2010. Eighteen randomized studies on this topic were evaluated.

RESULTS: Among these 18 studies, 7 (38.9\%) were multicenter and 11 (61.1\%) were single center. Totally 204 centers were involved. 1769 patients were treated surgically and 3200 medically. Craniotomy was the most preferred method ( $n=14 ; 77.8 \%$ ). Follow-up time was mostly 6 months. In general, the effect of surgical versus medical treatment on outcome (mortality/morbidity) after a supratentorial spontaneous $\mathrm{ICH}$ do not differ significantly. In individual analysis, the mortality was found to be significantly lower in the operated group than the nonoperated group in only two studies (Kurtsoy's and Miller's studies). Meta-analysis of subgroup analysis revealed surgical treatment results were significantly better for hematoma volume $>40 \mathrm{ml}$, early surgery (before 24 hours), and Glasgow Coma Scale (GCS) $\geq 6$.
\end{abstract}

CONCLUSION: Surgical treatment results were found to be superior to medical treatment in cases with hematoma volume $>40 \mathrm{ml}$, and GCS $\geq 6$. The studies are not adequate to analyze the best type of surgery.

KEYWORDS: Intracerebral hematoma, Meta-analyses, Surgery, Glasgow coma scale

öz

AMAÇ: Bu çalışmanın amacı, spontan intraserebral hematomun tedavisinde daha önceden yazılmış 18 randomize prospektif çalışmanın bulgularına dayanarak cerrahi tercih durumlarını belirlemek ve medikal ile cerrahi tedavi sonuçlarının etkinliğini karşılaştırmaktır.

YÖNTEM ve GEREÇ: 1960-2010 yılları arasında veritabanları taranarak ilgili makaleler araştııılı. Bu konu üzerine 18 randomize çalışma değerlendirildi.

BULGULAR: On sekiz çalışmanın 7si $(\% 38,9)$ çok merkezli, 11'i $(\% 61,1)$ tek merkezliydi. Toplam 204 merkez dahildi. 1769 hastaya cerrahi, 3200 hastaya medikal tedavi uygulandı. Kraniotomi en çok tercih edilen yöntemdi ( $n=14 ; \% 77,8)$. Takip süresi çoğunlukla 6 aydı. Genel olarak supratentorial spontan ICH sonrası sonuçlarda (mortalite ve morbiditede) cerrahinin medikal tedaviye etkinliği anlamlı farklı bulunmadı. Bireysel analizlerde sadece iki çalışmada(biri Kurtsoy'un ve diğeri Miller'ın) mortalite opere olan grupta opere olmayanlara göre daha düşük bulundu. Alt grupların meta-analizinde cerrahi tedavi hematom hacmi $40 \mathrm{ml}$ üstünde, erken cerrahide (24 saatten önce), Glasgow koma skalası 6 ve üzerinde anlamlı üstün bulundu.

SONUÇ: Hematom hacmi 40 mlden büyük, GCS 6 ve üzerinde olgularda cerrahi sonuçlar medikal tedaviden üstün bulundu. Çalışmalar en iyi cerrahi tipini belirlemek için yeterli değildir.

ANAHTAR SÖZCÜKLER: İntraserebral hematom, Metaanaliz, Cerrahi, Glasgow koma skalası

\section{INTRODUCTION}

The management and the effectiveness of the surgical treatment of spontaneous intracerebral hematoma $(\mathrm{ICH})$ are still controversial. There is no clear indication of the optimal treatment choice for ICH; surgical or otherwise. Current clinical practice seems varied. Proper evaluation of the role of surgery on spontaneous ICH should be provided $(8,29)$. In fact, 18 randomized trials $(1,2,4,6,7,11,13,14,15,17,18,19,22,23,24,26,2$
$7,29)$ have been published on the surgical evacuation versus medical treatment of spontaneous ICH. The first, carried out in 1961 by McKissock et al (17), revealed no benefit from surgical treatment. This study had a strong influence on neurosurgical practice, even nowadays (8). Studies by Juvela et al (14) in 1989, Batjer et al (2) in 1990, Morgenstren et al (21) in 1998, Zuccarello et al (28), Kurtsoy et al (15) and Miller et al (19) were all too small in number of patients to be conclusive. Auer et al (1) in 1989 found a significant benefit from endoscopic 
evacuation of ICH only in subcortical hematomas.

To investigate the feasibility of surgical treatment of $\mathrm{ICH}$, we analyzed and reviewed eighteen randomized studies on surgical treatment versus current non-operative management in patients with spontaneous supratentorial $\mathrm{ICH}$.

\section{MATERIAL and METHODS}

A literature search was performed using PUBMED, MEDLINE, EMBASE-Excerpta Medica databases from 1960 to 2010 on randomized studies for the treatment of spontaneous $\mathrm{ICH}$. Reference lists of all the articles identified were also examined, and relevant cited references were similarly reviewed. Eighteen randomized prospective studies between the years 1960-2010 were included. All available data were then combined to be analyzed as a whole.

The summaries of the studies are given in Table I.

Statistical analysis was performed via the computer-based software SPSS 16.0 and NCSS for windows.

Simple descriptives were used for total, minimum and maximum number of centers and number of patients (surgical, medical, totally) and age while simple descriptives and frequencies were used for administration time and surgical time.

Age was divided into two groups as below and above 65 years of age.

Admission and surgical time were evaluated in two groups as before and after 24 hours.

Hematoma dimensions were given as volume and/or diameter and/or depth, and the distribution among studies was analyzed by simple descriptives.

$\mathrm{ICH}$ volume was grouped into four groups: group $1:<10 \mathrm{ml}$, group 2:10-40ml, group 3:40-80ml and group 4:>80ml.

Glasgow Coma Scale (GCS) was evaluated in 4 groups;

Group 1 (3-5): very severe

Group 2 (6-8): severe

Group 3 (9-12): moderate

Group 4 (13-15):mild

All available data from included studies were entered and combined to be analyzed as a whole by using the wellestablished meta-analysis methods. Using the end points of death and dependency, the results were expressed as odds ratios with their associated 95\% confidence intervals. Significance was assigned at a $p$ value $<0.05$

\section{RESULTS}

An elegant description of the relevant details of the previously meta-analyzed trials is already available and will not be repeated here.

All included studies are summarized in Table I.

In this meta-analysis we analyzed all parameters of 18 studies.
Among 18 studies 7 (38.9\%) were multicenter, 11 (61.1\%) were single center. A total of 204 centers participation was included.

A total of 5511 patients were involved in 18 studies; the minimum number of total patients in a study was 10 , and the maximum was 1578. In the study by Gregson et al (11) on 542 patients, neurosurgeons were not sure of the treatment which mostly appropriate treatment and/or informed consent could not be obtained. Those patients were excluded and the final total number of patients was 4969.1769 patients were treated surgically and 3200 medically (Table II).

The admission time was reported in 10 studies. Among these studies, admission time was the first 6 hours in $1(10 \%)$, the first 12 hours in 2 (20\%), the first 24 hours in 5 (50\%) and the first 72 hours in 2 (20\%) (Table III).

Age range of all studies was 15 to 80 years with a mean of $64.2 \pm 15.5$ years.

Hematoma location was supratentorial in all studies. Hematoma dimensions were given as volume and/or diameter. Hematoma volume distribution among eleven studies was 10 to $100 \mathrm{~cm} 3$. In four studies mean hematoma volume was used; minimum $40 \mathrm{~cm} 3$ and maximum $96 \mathrm{~cm} 3$. In four studies hematoma diameter was used; minimum $2 \mathrm{~cm}$, maximum $5 \mathrm{~cm}$. Hematoma depth was given in three studies, among these the range was $1-2 \mathrm{~cm}$.

Surgery time was reported in 15 studies. In the study Sun DTF et al (26) surgical time was evaluated in two groups as early (before 24 hours) and late surgery (after 24 hours). Thus 16 surgical time results were present in 15 studies; surgery time was within 3 hours of submission in $1(6.25)$, within 6 hours in $1(6.25 \%)$, within 12 hours in $2(12.5 \%)$, before 24 hours in $5(31.25 \%)$, after 24 hours in $2(12.5 \%)$, within 48 hours in=3 (18.75\%) and within 72 hours in=2 (12.5\%) (Table IV).

Surgical type was reported in 17 studies. The types of surgery are given in Table V. Craniotomy was the most preferred method ( $n=14 ; 77.8 \%)$. In three studies two types (craniotomy and stereotactic in both, stereotactic and stereotactic plus fibrinolytic in one), in two studies three types (craniotomy, stereotactic surgery, EVD) and in one study four types (craniotomy, stereotactic, endoscopic, simple aspiration with burr-hole) of surgical procedures were used.

Follow-up time was given in 14 studies, varied 1-24months and preferred, mostly at 6 months $(n=9)$.

Meta-analysis of the effect of surgical versus medical treatment on outcome (mortality/morbidity) after a supratentorial spontaneous ICH indicate a nonsignificant increase $(p=0.822)$ in the odds (0.92) of death and dependency at 6 months for patients treated surgically (Table VI).

Subgroup analyses were carried out for the effect of admission time, age, hematoma volume, surgical time and GCS on mortality and morbidity. Admission time, age factor did not make a significant effect on mortality or morbidity. In cases with hematoma volume $>40 \mathrm{ml}$, surgical treatment results were significantly better regarding mortality $(p=0.04)$ and 


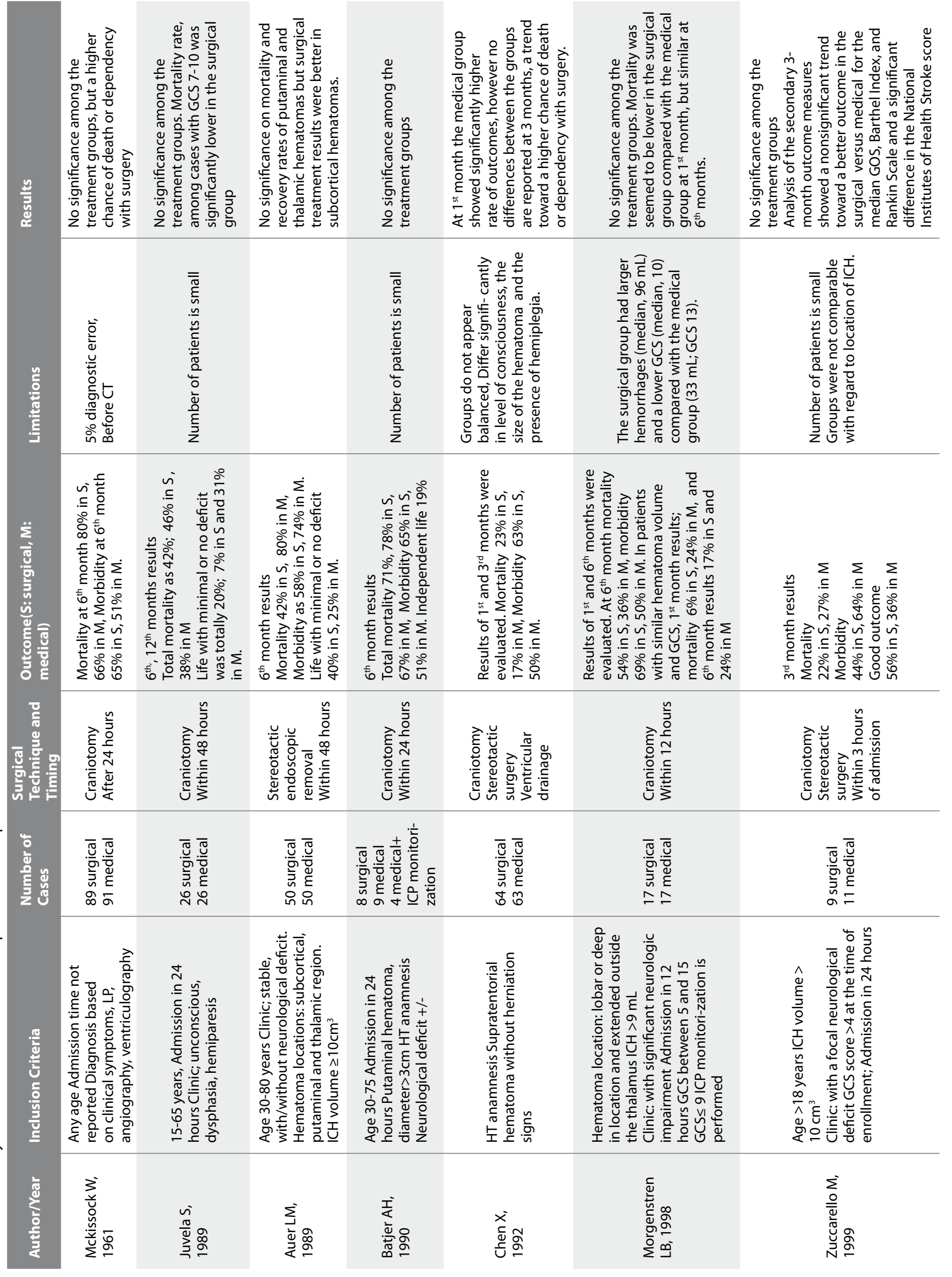




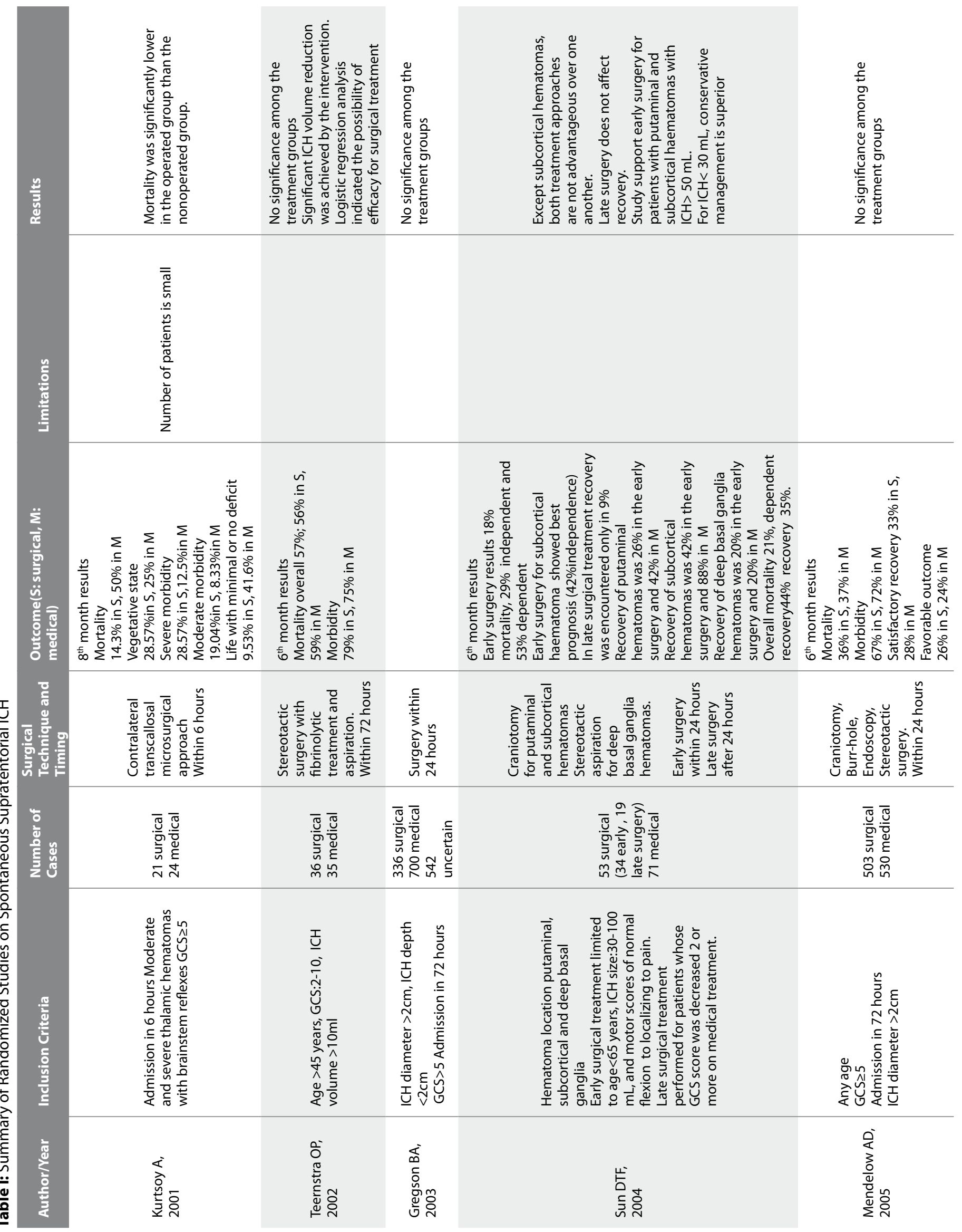




\begin{tabular}{|c|c|c|c|c|c|}
\hline 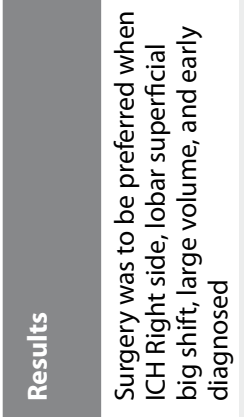 & 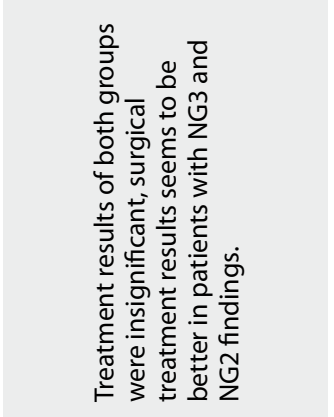 & 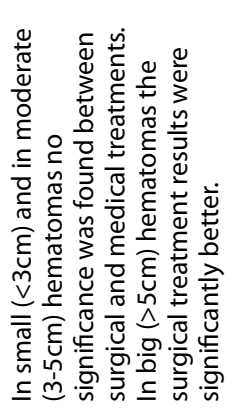 & 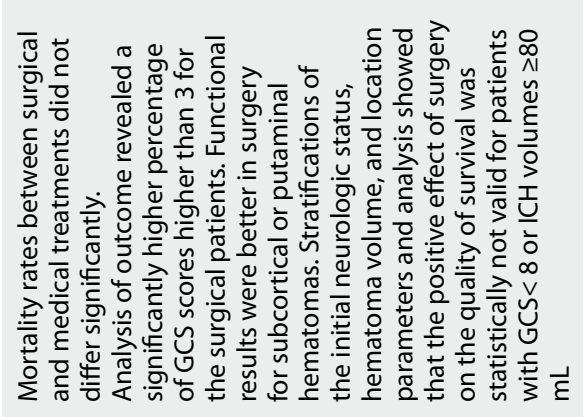 & 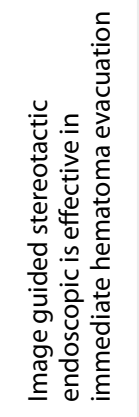 & 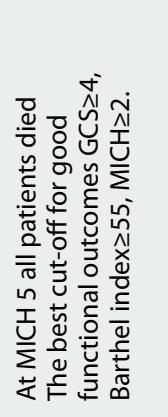 \\
\hline 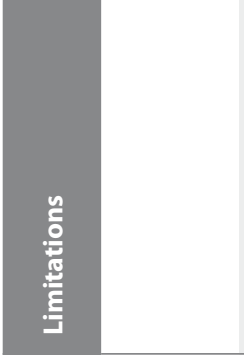 & & & & 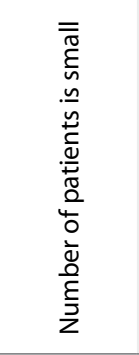 & 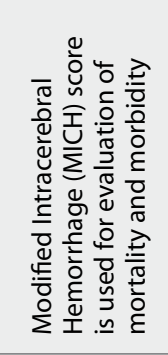 \\
\hline 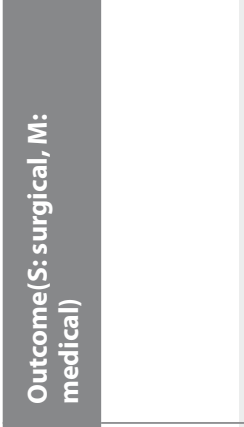 & 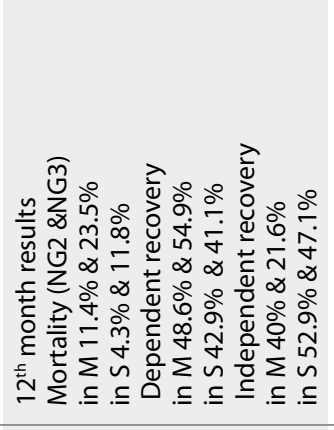 & & 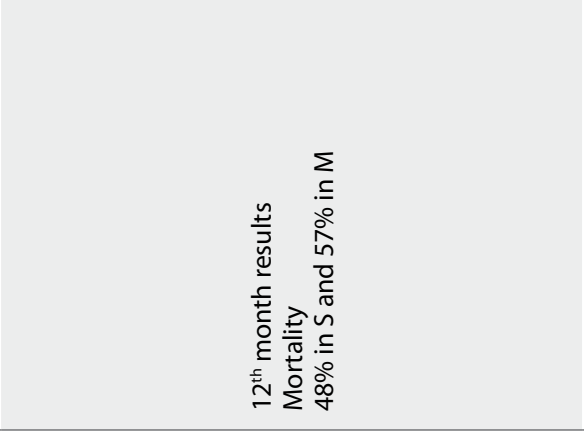 & 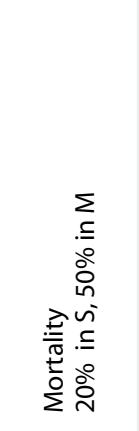 & 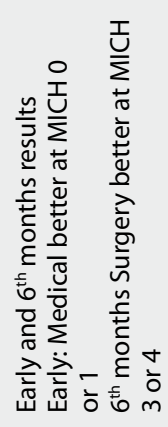 \\
\hline 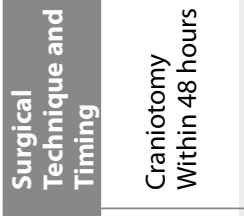 & 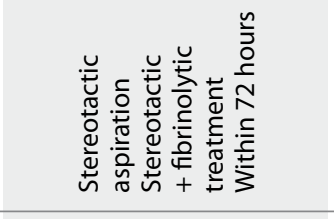 & 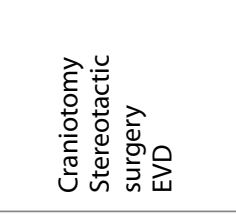 & 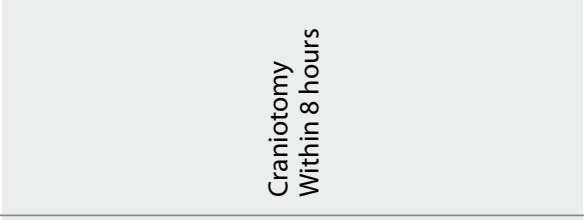 & 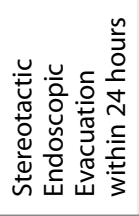 & 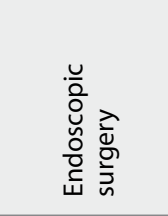 \\
\hline 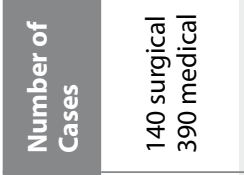 & 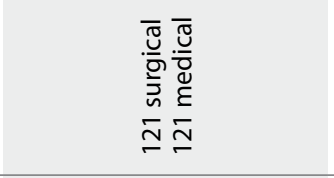 & 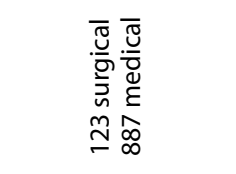 & 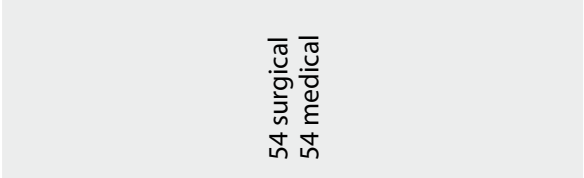 & 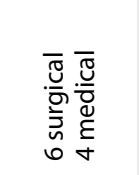 & 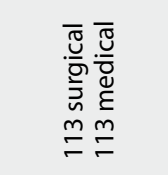 \\
\hline 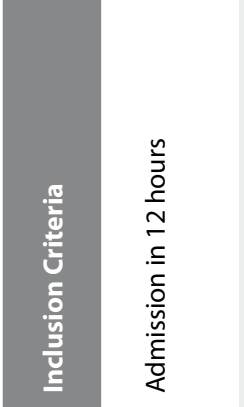 & 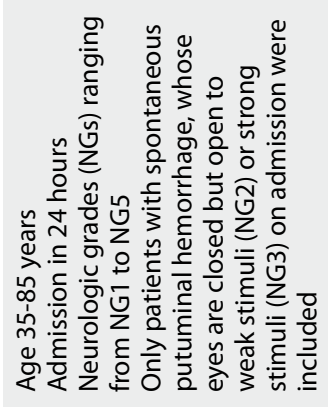 & 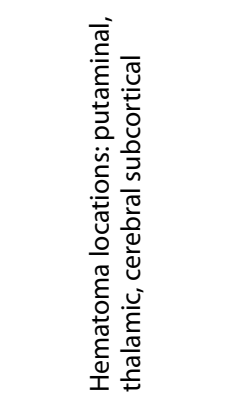 & 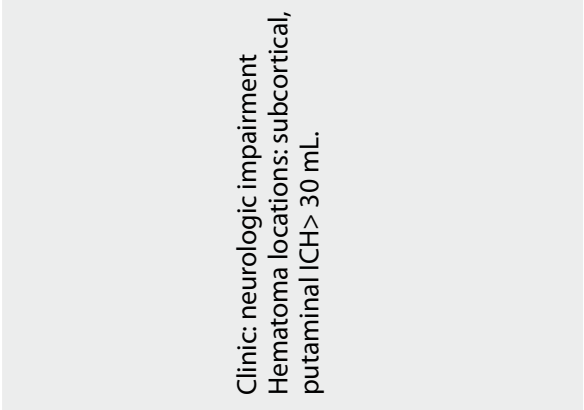 & 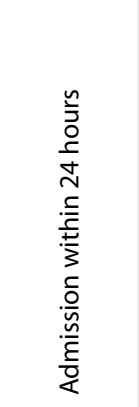 & 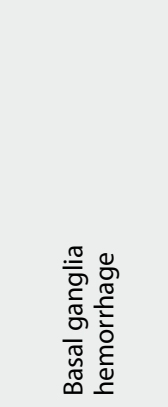 \\
\hline 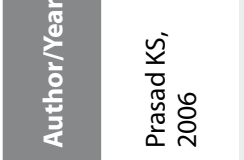 & 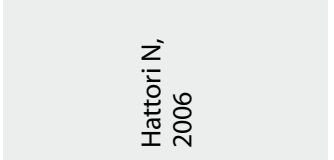 & 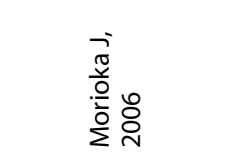 & 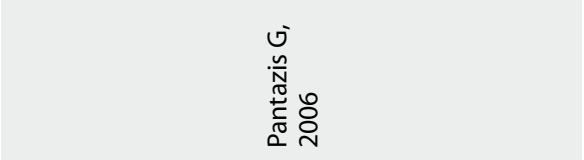 & 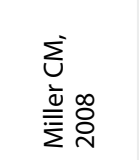 & 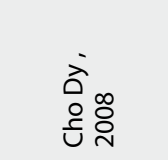 \\
\hline
\end{tabular}


Table II: Total Number of Centers \& Patients, Surgically \& Medically Treated Patients

\begin{tabular}{|c|c|c|c|c|c|}
\hline & $\begin{array}{l}\text { Number of } \\
\text { centers involved }\end{array}$ & $\begin{array}{l}\text { Total number } \\
\text { of patients } \\
\text { involved }\end{array}$ & $\begin{array}{l}\text { Total number of } \\
\text { patients finally } \\
\text { involved }\end{array}$ & $\begin{array}{l}\text { Number of } \\
\text { surgically } \\
\text { treated patients }\end{array}$ & $\begin{array}{c}\text { Number of } \\
\text { medically } \\
\text { treated patients }\end{array}$ \\
\hline Grand total sum & 204 & 5511 & 4969 & 1769 & 3200 \\
\hline Minimum & 1 & 10 & 10 & 6 & 4 \\
\hline Maximum & 83 & 1578 & 1036 & 503 & 887 \\
\hline
\end{tabular}

Table III: Admission Time

\begin{tabular}{l|c|c|} 
& Frequency & Percent \\
\hline first 6 hours & 1 & 10 \\
\hline first 12 hours & 2 & 20 \\
first 24 hour & 5 & 50 \\
first 72 hours & 2 & 20 \\
\hline Total & 10 & 100 \\
\hline
\end{tabular}

Number of studies that had reported admission times are listed in frequency and percents.

Table IV: Surgical Time

\begin{tabular}{|l|c|c|}
\hline within 3 hours of admission & 1 & Percent (\%) \\
\hline within 6 hours & 1 & 6,25 \\
\hline within 12 hours & 2 & 6,25 \\
\hline before 24 hours & 5 & 12,5 \\
\hline after 24 hours & 2 & 31,25 \\
\hline within 48 hours & 3 & 12,5 \\
\hline within 72 hours & 2 & 18,75 \\
\hline Total & 16 & 12,5 \\
\hline
\end{tabular}

Number of studies that had reported surgical times are listed in frequency and percents.

Table V: Surgical Types

\begin{tabular}{l|c} 
& Frequency \\
\hline Simple asp with burr hole & 6 \\
Craniotomy & 14 \\
Stereotactic & 6 \\
Stereotactic with fibrinolytic & 2 \\
\hline Endoscopic & 6 \\
\hline Stereotactic endoscopic & 1 \\
EVD & 2 \\
\hline Contrlateral transcallosal approach & 1 \\
\hline
\end{tabular}

Number of studies that had reported surgical types are listed in frequency and percents.

Note: More than one type of surgery were reported in some studies. morbidity ( $p=0.019$ ). Early surgery (before 24 hours) favours the outcome regarding morbidity significantly $(p=0.01)$ and mortality but insignificantly $(p=0.075)$. The endoscopic approach yielded a better outcome for morbidity $(p=0.048)$. In cases with $G C S \geq 6$, surgical results were found to be better for mortality $(p=0.035)$ and for morbidity $(p=0.044)$.

\section{DISCUSSION}

There is still debate among neurosurgeons and neurologist all over the world on the effective treatment of intracerebral hematoma $(\mathrm{ICH})$ and about whether it should be surgically or medically treated. Criterias on treatment decision include; patient's age, hematoma volume, location and deepness from the surface, Glasgow coma scale (GCS), pathologies underlying hematoma (aneurysm, AVM, trauma etc.), time duration between hemorrhage and diagnosis, severe coagulopathy or presence of underlying serious medical disease, progression on neurological deficits or conscious, development of obstructive hydrocephaly, and compression of brain stem $(3,8,9)$. However, The STICH (surgical treatment for intracerebral haemorrhage) study showed no overall benefit from early surgery when compared with initial conservative treatment (25).

The aim of surgical treatment in $\mathrm{ICH}$ can be summarized briefly as'removing the most hematoma volume in the fastest way and with minimum surgical damage as possible'. If there is an underlying pathology of the hematoma, intervention should also be performed to that lesion during the surgery $(3,8,9)$.

The percentage of preferring surgery changes in different countries. There are severe differences of surgical rates among countries and this can be attributed to the difference of patients' admission, to the difference of decision criteria among clinics, to the difference of centers' structure, to the difference of surgical expertise among countries and to the difference of people's expectations among countries. $(11,26)$

Surgical indication criterion of supratentorial hematomas include; progressive deterioration of consciousness, increased edema on CT, determining AVM, aneurysm or tumor on MRI and angiography, development of obstructive hydrocephalus, compression on brain stem, shift effect, patient age less than 80 , GCS of 5-11, lack of severe coagulopathy or presence of systemic disease, hematoma volume greater than $30 \mathrm{~cm} 3$ at cerebral and diameter greater than $3 \mathrm{~cm}$ at cerebellar region, hematoma location on non-dominant hemisphere, 
Table VI: Meta-analysis of the Effect of Surgical Versus Medical Treatment on Outcome at 6th Months (mortality/morbidity) after a Supratentorial Spontaneous ICH $(p=0.822)$

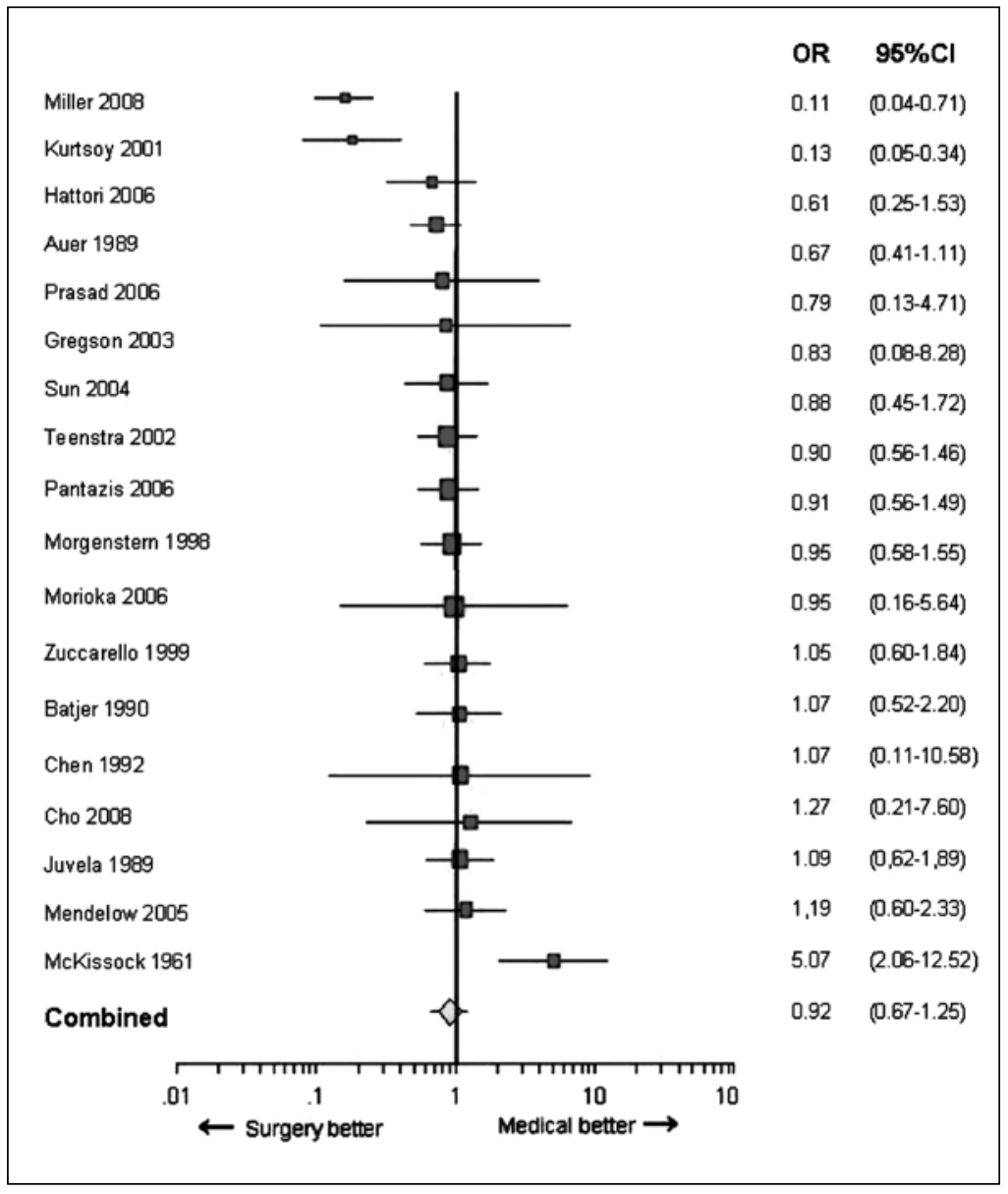

lobar and external capsule $(1,4,6,7,11,13,14,19,22,23,26,2$ $7,29)$. In Broderick et al's study (3) surgical treatment was recommended for cases with low GCS, lobar hematoma, hematoma near surface and wide hematoma.

A medical approach is preferred for the patients with; hematoma volume $\leq 10 \mathrm{~cm} 3$ or $\geq 60 \mathrm{~cm} 3$ in supratentorial hemorrhage or for cases demonstrating minimal neurological deficit, in cases that would have very good or very poor prognosis, who have GCS greater than 10 or GCS less than five respectively or extravasation of contrast medium at hematoma area on $\mathrm{CT}$, for cases with severe coagulopathy or presence of underlying serious medical disease, for very old (over 80 ) cases that would not tolerate operation and for pontine hematomas which are $60 \%$ fatal $(4,7,17,26)$

Surgical methods includes; simple aspiration (with Burr-hole), open craniotomy, decompression and removal of hematoma, fibrinolytic treatment, stereotactic surgery with fibrinolytic treatment, neuroendoscopic surgery with fibrinolytic treatment and stereotactic endoscopic removal $(1,4,6,7,11,1$ $3,14,19,22,23,26,27,29)$. In contrast, the stereotactic aspiration technique can be safely performed and in a uniform manner. Despite the reduction of $\mathrm{ICH}$ volume, no improvement in mortality and functional result was obtained. Endoscopy is a new therapeutic option for $\mathrm{ICH}$ with good results for hematoma removal $(7,19,25)$

Timing of surgery is important. Early surgery decreases the toxic effects of blood and plasma products and this provides decrease of ischemia and edema of the neighboring glial tissues. Hematoma reaches its maximum dimensions in the first six hours (10). However very early surgery increases new hemorrhage risk. New hemorrhage risk after surgery is reported to be $40 \%$ in 4 hours and $12 \%$ in 12 hours by Morganstern et al (20), and $22 \%$ in 3-5 and $9 \%$ in 6-8 by Pantazis et al (23).

Simple aspiration by Burr-hole can be used in emergent cases. It can be performed by local anesthesia. Technically aspiration is performed after placing a catheter into hematoma but it is not preferred nowadays. Only a small volume of hematoma can be aspirated. It can cause new hemorrhage since aspiration is performed in a blind way (18).

Craniotomy is a standard approach. It can be performed with decompressive craniectomy and duraplasty. It allows intervention to underlying pathology of hematoma. Adequate amount of hematoma can be aspirated. Bleeding control is easy $(2,14,17,21,23,24,29)$.

Fibrinolytic treatment dissolves the blood rapidly and draining or aspiration. Fibrinolytic agents that can be used are urokinase and tissue fibrinogen activator (rTPA). Urokinase is applied as $5000-10000 \mathrm{U}$ in $5 \mathrm{ml}$ saline solution 1 to 4 times a day, treatment should be continued for 7 or more days. rTPA is applied as $2 \mathrm{mg} / 12$ hours for $2-4$ days or $5 \mathrm{mg} / 24$ hours for $2-4$ days. Fibrinolytic treatment increases new hemorrhage risk $(13,27)$

In stereotactic surgery, a silicon catheter is placed in hematoma location by stereotactic method. Initially the technique was only used for aspiration, recently it is used with fibrinolytic treatment. It can be performed under local anesthesia. Catheter is placed in the center of the hematoma $(13,27)$.

Neuroendoscopic surgery is used for especially putaminal and thalamic wide hematomas $(5,7)$. Under general anesthesia burr-holes from both frontal regions are performed, hematoma is aspirated through ventricle. Endoscope also can be replaced by stereotactic frame. It can also be performed as endoscopic aspiration of the hematoma through a study canule passing the opening of single burr-hole from the ipsilateral side. $(5,7)$. Third ventriculostomy can be performed. Both lateral ventricle atria, frontal horns and third ventricle can be aspirated. Sometimes with $30^{\circ}$ telescopes temporal horns and forth ventricle can be seen (28). 
The results of the randomized studies we included in our analysis revealed in 18 studies $(1,2,4,6,7,11,13,14,15,17,1$ $8,19,22,23,24,26,27,29)$ overall no significance was found among surgical and medical studies. Only in two studies by Kurtsoy A et al (15) and Miller et al (19) was mortality found to be significantly lower in the operated group than the nonoperated group, although the number of included patients was limited (21 surgically, 24 medically treated in Kurtsoy's (15) and 6 surgically, 4 medically treated in Miller's studies). The most striking differences of Kurtsoy's (15) study from others are firstly the surgical technique, contralateral transcallosal microsurgical approach, in very early stage (within 6 hours), the second is the short admission time criteria (within 6 hours) and the third is they only included patients with moderate and severe thalamic hematomas with brainstem reflexes with $G C S \geq 5$. Miller et al (19) used stereotactic hematoma evacuation technique.

When we further analyze the results we found out that in two studies $(4,17)$ in general and in one study $(26)$ only for $\mathrm{ICH}<$ $30 \mathrm{~mL}$, medical treatment was reported to be insignificantly superior. Surgery results seemed better overall in the early period of two studies $(21,29)$ but later no difference was found (21). A significant ICH volume reduction was achieved by the intervention (27). Surgical treatment results were found to be superior to medical treatment results in subcortical $(1,23,24,26)$, putaminal $(22,23,26)$ right sided $(24)$, lobar $(24)$ hematomas, in large hematoma volume $(>5 \mathrm{~cm}$ diameter or $>50 \mathrm{ml}$ volume $(22,24,26)$, in hematomas that caused a big shift (24) and in patients with moderate GCS $(7,14,23)$. Early surgery improves surgical results, thus to be preferred $(15,24,26)$.

\section{The studies reporting medical treatment is advantageous over surgical reveal:}

- No significance among the treatment groups, but a higher chance of death or dependency with surgery (17)

- At 1st month the medical group showed significantly higher rate of outcomes, however no differences between the groups are reported at 3 months, a trend toward a higher chance of death or dependency with surgery (4)

- For $\mathrm{ICH}<30 \mathrm{~mL}$, conservative management is superior (26)

The studies reporting surgical treatment is advantageous over medical reveal:

- No significance on mortality and recovery rates of putaminal and thalamic hematomas but surgical treatment results were better in subcortical hematoma. (1)

- Mortality rate, among cases with GCS 7-10 was significantly lower in the surgical treatment group than in the medical. (14)

- Mortality was seemed to be lower in the surgical group compared with the medical group at 1 st month, but similar at 6th months (21)
- Analysis of the secondary 3-month outcome measures showed a nonsignificant trend toward a better outcome in the surgical versus medical for the median GOS, Barthel Index, and Rankin Scale and a significant difference in the National Institutes of Health Stroke Scale score $(7,13,29)$

- A significant ICH volume reduction was achieved by the intervention $(7,19,27)$

- Early surgery in patients with putaminal and subcortical haematomas with $\mathrm{ICH}>50 \mathrm{ml}$ is superior $(6,22,23,26)$

- Surgery was to be preferred when ICH had these features: Right side, lobar location, superficial, large volume, big shift, and early diagnosed and treated patients $(23,24,26)$

- In hematomas $>5 \mathrm{~cm}$ the surgical treatment results were significantly better $(22,23)$

\section{The main question to be answered is which cases we should operate?}

Fewel et al (9) suggested that surgery should be considered in patients with moderate to large lobar or basal ganglia hemorrhages and those suffering progressive neurological deterioration, Proust et al (25) suggested supratentorial craniotomy for patients with GCS $>8, \mathrm{HC}$ volume of $10-40 \mathrm{ml}$, lobar or for hematomas located at about $1 \mathrm{~cm}$ to cortical surface.

According to our meta-analysis results patients with the GCS score $\geq 6$, and those with hematoma volume greater than $40 \mathrm{ml}$ benefit from surgery.

The second question is which surgical technique we should choose?

According to Zuccarello et al (29) removed hematoma volume in craniotomy group is greater than stereotactic group. According to Morioka J (22) there is no significant difference between craniotomy and stereotactic operation on patients last state. Craniotomy has the longest operation time. Blood loss is reported to be most significant in the craniotomy. The highest hematoma evacuation rate was seen in the endoscopic surgery $(5,7)$. In Cho's study (5) the mortality rate was $0 \%, 6.7 \%$ and $13.3 \%$ and the complication rate was $3.3 \%$, $10 \%$ and $16.6 \%$ in endoscopic aspiration surgery group, in stereotactic aspiration and fibrinolytic treatment group, and in craniotomy group respectively. Both endoscopic surgery and stereotactic aspiration are minimally invasive and are effective procedures with low complication and mortality rates; however, the waiting timing of stereotactic aspiration is usually longer. Endoscopic surgery may be an appropriate substitute for stereotactic aspiration. It produces good neurological outcomes and aids in rapid hematoma. $(5,7,19)$. In 18 studies we analyzed, only in Kurtsoy A et al's (15) and Miller's et al (19) studies mortality was found significantly lower in the operated group than the nonoperated group. The surgical technique was contralateral transcallosal microsurgical approach and endoscopic evacuation respectively $(15,19)$. However according to our meta-analysis the studies are not enough to analyze the best surgical type. 


\section{The third question is when we should operate?}

Acute management of deep-seated hematomas remains controversial. Since patients with these hematoma later tend to develop severe edema and necrosis around the lesion, when surgery is indicated it should be done as early as possible (15). According to our meta-analysis results early surgery improves outcome.

\section{CONCLUSION}

We conclude that operation is to be the preferred choice of treatment for the cases GCS $\geq 6$ and for large hematomas $(>40 \mathrm{ml}$ volume). Early surgery especially within 24 hours improves surgical results. Although craniotomy is the most preferred method, endoscopic technique seems to provide decreased morbidity and mortality rates. However the studies are not enough to analyze the best surgical type.

\section{REFERENCES}

1. Auer LM, Deinsberger W, Niederkorn $K$, Gell G, Kleinert $R$, Schneider G, Holzer P, Bone G, Mokry M, Korner E, et al: Endoscopic surgery versus medical treatment for spontaneous intracerebral hematoma: A randomized study. J Neurosurg 70:530-535, 1989

2. Batjer HH, Reisch JS, Allen BC, Plaizier LJ, Su CJ: Failure of surgery to improve outcome in hypertensive putaminal hemorrhage. A prospective randomized trial. Arch Neurol 47:1103-1106, 1990

3. Broderick JP, Adams HP Jr, Barsan W, Feinberg W, Feldmann $E_{,}$ Grotta J, Kase C, Krieger D, Mayberg M, Tilley B, Zabramski JM, Zuccarello M: Guidelines for the management of spontaneous intracerebral hemorrhage: A statement for healthcare professionals from a special writing group of the Stroke Council, American Heart Association. Stroke 30:905-915, 1999

4. Chen $X$, Yang $H$, Czherig Z: A prospective randomised trial of surgical and conservative treatment of hypertensive intracranial haemorrhage. Acta Acad Med Shanghai 19:237-240, 1992

5. Cho DY, Chen CC, Chang CS, Lee WY, Tso M: Endoscopic surgery for spontaneous basal ganglia hemorrhage: comparing endoscopic surgery, stereotactic aspiration, and craniotomy in noncomatose patients. Surg Neurol 65:547- 556, 2006

6. Cho DY, Chen CC, Lee HC, Lee WY, Lin HL: Glasgow Coma Scale and hematoma volume as criteria for treatment of putaminal and thalamic intracerebral hemorrhage. Surg Neurol 70:628-633, 2008

7. Cho DY, Chen CC, Lee WY, Lee HC, Ho LH: A new Modified Intracerebral Hemorrhage score for treatment decisions in basal ganglia hemorrhage--a randomized trial. Crit Care Med 36: 2151-2156, 2008

8. Fernandes HM, Gregson B, Siddique S, Mendelow AD: Surgery in intracerebral hemorrhage. The uncertainty continues. Stroke 31:2511-2516, 2000

9. Fewel ME, Thompson BG, Hoff JT: Spontaneous intracerebral hemorrhage: A review. Neurosurg Focus 15(4):E1, 2003

10. Fujii $Y$, Tanaka R, Takeuchi $S$, Koike $T$, Minakawa $T$, Sasaki O: Hematoma enlargement in spontaneous intracerebral hemorrhage. J Neurosurg 80:51-57, 1994

11. Gregson BA, Mendelow AD: STICH Investigators. International variations in surgical practice for spontaneous intracerebral hemorrhage. Stroke 34: 2593-2597, 2003

12. Hankey GJ, Hon C: Surgery for primary intracerebral hemorrhage: Is it safe and effective? A systematic review of case series and randomized trials. Stroke 28:2126-2132, 1997
13. Hattori N, Katayama Y, Maya Y, Gatherer A: Impact of stereotactic hematoma evacuation on medical costs during the chronic period in patients with spontaneous putaminal hemorrhage: A randomized study. Surg Neurol 65:429-435, 2006

14. Juvela $S$, Heiskanen $O$, Poranen A, Valtonen $S$, Kuurne T, Kaste $M$, Troupp $H$ : The treatment of spontaneous intracerebral hemorrhage. A prospective randomized trial of surgical and conservative treatment. J Neurosurg 70: 755-758, 1989

15. Kurtsoy A, Oktem IS, Koc RK, Menku A, Akdemir H, Tucer B: Surgical treatment of thalamic hematomas via the contralateral transcallosal approach. Neurosurg Rev 24: 108-113, 2001

16. Little KM, Alexander MJ: Medical versus surgical therapy for spontaneous intracranial hemorrhage. Neurosurg Clin N Am 13:339-347, 2002

17. McKissock W, Richardson A, Taylor J: Primary intracerebral haemorrhage: A controlled trial of surgical and conservative treatment in 180 unselected cases. Lancet 2:221-226, 1961

18. Mendelow AD, Gregson BA, Fernandes HM, Murray GD, Teasdale GM, Hope DT, Karimi A, Shaw MD, Barer DH, STICH Investigators: Early surgery versus initial conservative treatment in patients with spontaneous supratentorial intracerebral haematomas in the International Surgical Trial in Intracerebral Haemorrhage (STICH): A randomised trial. Lancet 365:387-397, 2005

19. Miller CM, Vespa P, Saver JL, Kidwell CS, Carmichael ST, Alger J, Frazee J, Starkman S, Liebeskind D, Nenov V, Elashoff R, Martin $\mathrm{N}$ : Image-guided endoscopic evacuation of spontaneous intracerebral hemorrhage. Surg Neurol 69:441-446, 2008

20. Morgenstern LB, Demchuk AM, Kim DH, Frankowski RF, Grotta JC: Rebleeding leads to poor outcome in ultra-early craniotomy for intracerebral hemorrhage. Neurology 56:1294-1299, 2001

21. Morgenstern LB, Frankowski RF, Shedden P, Pasteur W, Grotta JC: Surgical treatment for intracerebral hemorrhage (STICH): A single-center, randomized clinical trial. Neurology 51:1359-1363, 1998

22. Morioka J, Fujii $M$, Kato $S$, Fujisawa $H$, Akimura T, Suzuki $M$, Kobayashi S, Japan Standard Stroke Registry Group (JSSR): Surgery for spontaneous intracerebral hemorrhage has greater remedial value than conservative therapy. Surg Neurol 65:67-73, 2006

23. Pantazis G, Tsitsopoulos P, Mihas C, Katsiva V, Stavrianos V, Zymaris $S$ : Early surgical treatment vs conservative management for spontaneous supratentorial intracerebral hematomas: A prospective randomized study. Surg Neurol 66:492-501, 2006

24. Prasad KS, Gregson BA, Bhattathiri PS, Mitchell P, Mendelow AD: The significance of crossovers after randomization in the STICH trial. Acta Neurochir Suppl 96:61-64, 2006

25. Proust F, Leveque S, Derrey S, Tollard E, Vandhuick O, Clavier E, Langlois O, Fréger P: Spontaneous supratentorial cerebral hemorrhage: Role of surgical treatment. Neurochirurgie 53: 58-65, 2007

26. Sun DTF, Tsang YYY, Poon WS: Intracerebral haematoma: Operative versus non-operative. Ann Coll Surg HK 8:55-58, 2004

27. Teernstra OP, Evers SM, Lodder J, Leffers $P$, Franke $C L$, Blaauw $G$ : Stereotactic treatment of intracerebral hematoma by means of a plasminogen activator: A multicenter randomized controlled trial (SICHPA). Stroke 34: 968-974, 2003

28. Yadav YR, Mukerji G, Shenoy R, Basoor A, Jain G, Nelson A: Endoscopic management of hypertensive intraventricular haemorrhage with obstructive hydrocephalus. BMC Neurol Jan 4, 7:1, 2007

29. Zuccarello $M$, Brott T, Derex L, Kothari R, Sauerbeck L, Tew J, Van Loveren H, Yeh HS, Tomsick T, Pancioli A, Khoury J, Broderick $\mathrm{J}$ : Early surgical treatment for supratentorial intracerebral hemorrhage: a randomized feasibility study. Stroke 30:18331839, 1999 